\title{
Cultural Mismatch in Pedagogy Workshops: Training Non-native Teachers in Communicative Language Teaching
}

\author{
Maria Luisa Spicer-Escalante \\ Department of Languages, Philosophy, and Communication Studies, Utah State University, Logan, Utah, USA \\ Karin deJonge-Kannan \\ Department of Languages, Philosophy, and Communication Studies, Utah State University, Logan, Utah, USA
}

\begin{abstract}
As a professional ideology, the Communicative Language Teaching approach (CLT) (Ellis, 1996, 2012; Lee \& VanPatten, 2003) has been exported to non-Western contexts with varying degrees of success (e.g., Lewis \& McCook, 2002; Li, 1998). The authors of this paper, both non-native speakers of English who have lived and taught in the USA for 20 years, discuss their experiences training teachers of English as a Foreign Language (EFL) from China and Iraq/Kurdistan. Confirming previous research on the topic, they found teachers' beliefs about teaching to be highly resistant to change, even in the face of evidence that negates them (Bax, 2003; Brown, 2009; Nespor, 1987; Pajares, 1992). This article analyzes the cultural parameters of EFL contexts that seem to be at the root of teachers' reluctance toward CLT. The authors argue that this hesitation is related to a mismatch between teachers' and trainers' belief systems. This phenomenon is explored in light of cultural and ideological factors. The authors draw on Kachru's $(1992,2006)$ work on the power dynamics between Inner Circle, Outer Circle, and Expanding Circle countries (see also Burns, 2013; Canagarajah, 2013).
\end{abstract}

Index Terms - EFL teacher training, non-native teachers, teaching English as an international language, the communicative approach, communicative language teaching, global workplace needs

\section{INTRODUCTION}

Following a recent presentation of this paper at an international conference, an audience member remarked that it was pointless expecting Chinese and Iraqi/Kurdish teachers to adopt the Communicative Approach to teach English as a Foreign Language (EFL) in their countries since teachers have to work within the cultural constraints of the countries in which they live. However, this view is no longer defensible. On the contrary, similar to their colleagues around the world, Chinese and Iraqi/Kurdish teachers of EFL live in a global context without communication boundaries, requiring them to meet the needs and to face the challenges that globalization entails. EFL instructors need to teach in such a way that students will be equipped with the necessary English skills that will enable them to perform in real life as they navigate the various professional, academic, and personal settings in which they will be networking.

Throughout history, people have moved from place to place, migrating to other countries and adapting themselves to new languages, other cultures, and different ways of living. However, the $21^{\text {st }}$ century and its new job market do not necessarily require people to relocate. Due to internet-supported connectedness, today's workplace demands that workers be proficient in English and able to carry out the tasks that their positions require (Neeley, 2012).

In light of the demands of the global workplace, this article discusses recent workshops for EFL teachers from China and Iraq/Kurdistan in which communicative, task-based activities characteristic of the communicative language teaching (CLT) approach (Ballman, Liskin-Gasparro \& Mandell, 2001) were employed. The first part of the article addresses the challenges that emerge when trying to export CLT to non-Western contexts, where teachers have their own beliefs about teaching, with which they are comfortable (Farrell, 2008). The next sections describe the methods, participants, procedures, and materials used, as well as an analysis and discussion regarding teachers' beliefs and cultural reluctance. Finally, implications for teaching and suggestions for future research are presented.

\section{Communicative Language Teaching And Its Challenges}

More than a decade ago, The Economist (2001) stated that English had become the global language and that most of the world was influenced by it. As many travelers can attest, English is "everywhere" and an ever-increasing percentage of the world's population is learning it.

[English] is everywhere. Some 380 million people speak it as their first language and perhaps two-thirds as many again as their second. A billion are learning it, about a third of the world's population are in some sense exposed to it and by 2050, it is predicted, half the world will be more or less proficient in it. It is the language of globalization - of 
international business, politics and diplomacy. It is the language of computers and the Internet. [...] It is now the global language. (The Economist, December 20, 2001)

Current statistics lend further support to this claim. According to the British Council (2014), around 750 million people speak English as a foreign language and "one out of four of the world's population speaks English to some level of competence", with an increasing and steady demand from the other three-quarters to learn it (British Council, 2014).

In the same vein, the Education First English Proficiency Index (EFEPI), a measure that ranks 60 countries and territories across the globe according to adult English proficiency, has stated that "year by year, economies are more globalized, work more delocalized, and information more decentralized. A shared language is a necessary tool when communication is no longer tied to geography" (EFEPI, 2013, p. 4). Currently, English is the vehicle that makes global communication possible, satisfying the multiple demands of diverse interactions and transactions that globalization entails. According to Graddol (2006), soon "there will be around 2 billion people learning English in many different contexts around the world" (Graddol, 2006, p. 100).

Due to the ever-increasing demand for English language learning, both China and Iraq/Kurdistan, as well as other non-English speaking countries, must prepare their students to carry out communicative tasks for professional purposes in the global workplace. To help build capacity to meet this need, we conducted a set of teacher training workshops. The workshops were designed according to the CLT approach, which is defined as a research-based approach to language teaching that emphasizes interaction as both the means and the ultimate goal of study (Ballman, LiskinGasparro \& Mandell, 2001; Lee \& VanPatten, 2003). In addition, CLT is goal-oriented and interaction-centered: the teacher is viewed as the facilitator or coach whose main role is to provide ample opportunities for students to use the target language in meaningful ways (Ellis, 1996, 2012; Lee \& VanPatten, 2003).

Under the CLT approach, teachers design task-based activities (TBAs) that promote communication and interaction among students and between students and instructor (Lee \& VanPatten, 2003). Although TBAs are learner-centered and require a specific communicative goal, making student-to-student interaction and the negotiation of meaning among participants imperative for successful completion of the task, they also allow teacher-fronted activities. As Ellis (2012) mentions, TBAs must not be exclusively learner-centered, as "task-based teaching is both teacher- and learner-centred" (Ellis, 2012, p. 233). Thus, students in CLT classrooms are engaged in TBAs with carefully incorporated teacherdirected instruction. Crucially, TBAs focus on a meaningful exchange of information on the part of participants, involving topics and scenarios from the real world. To accomplish the communicative goal, TBAs carefully guide participants through a series of pre-determined steps that culminate in a concrete representation of the information shared or gathered (Ballman, Liskin-Gasparro \& Mandell, 2001).

\section{A. Why Focus on Communicative Language Teaching?}

In terms of adult English proficiency, China is ranked $34^{\text {th }}$ out of 60 countries in the most recent EFEPI report (2013), and is classified as a low-proficiency country, outperforming only Thailand and Kazakhstan within Asia. At the same time, Iraq, which was indexed for the first time in 2013 , holds the last place, $60^{\text {th }}$ out of 60 , and is classified as a very low proficiency country according to EFEPI criteria (EFEPI, 2013).

Regarding China, the EFEPI report declares that in order to promote economic growth and become more competitive, China "needs to continue improving English teaching in public schools, training teachers to use communicative teaching methods, and revising high-stakes exams to include assessment of oral skills" (EFEPI, 2013, p. 13). Although China produces a great number of graduates each year, only a small percentage will have the English skills necessary for professional international communication (Farrell \& Grant, 2005; Graddol, 2006; Yang, 2006). As Farrell and Grant declared regarding the 3.1 million students graduating from diverse colleges in China in 2004, "less than 10 percent of Chinese job candidates on average would be suitable for work in a foreign company. [...] The chief handicaps are weak spoken-English skills, especially among graduates of non-elite schools, and the uneven quality of college curricula and faculty" (Farrell \& Grant, 2005, p. 6).

Despite these realities and regardless of continual efforts since the early 1970s, China has not been successful in implementing CLT. One of the reasons, to be discussed later in this article, is the teachers' resistance to changing their teaching methodologies. Of course, China is not alone in this position; it has been noted by various researchers that CLT methods are not generally used in EFL programs (Burns, 2013; Canagarajah; 2013; EFEPI, 2013). Traditional methods of teaching English, consisting of long grammar explanations, verb conjugations, and vocabulary lists, as well as mechanical drills, repetitions, and sentence transformation exercises, still feature regularly in EFL classrooms around the world. Nevertheless, as countries start to respond to the rise of global requirements, the need for the implementation of CLT becomes greater.

Thus, EFL teachers find, or will soon find, themselves faced with the inevitable need to teach their students how to use English in real-world situations such as explaining their professional and personal skills at a job interview, talking on the phone to non-native speakers from other countries, sending a company memo explaining problems faced in their division, writing a contract, etc. As Graddol (2006) emphasizes, English teachers must prepare their students for the global employment context "where broader education or employment is dependent on actual [English] skills (rather than token certification)" (Graddol, 2006, p. 92). This is, indeed, the hallmark of CLT and the main characteristic of TBA: to prepare students to perform real-life tasks in scenarios that they are likely to encounter in their personal and professional lives, away from fill-in-the-blank exams, memorization of grammatical rules, and multiple choice tests. 
The need for EFL learners to improve their English skills so that they can accomplish real-world tasks cannot be ignored and this need must be met through the work of EFL teachers. Not only will students need English proficiency after they graduate, they will also need it during the time they are still students. For example, in 2011, China "became the world's top source of overseas students by sending 339,700 students. [...] More than half of these Chinese students traveled to the U.S., the U.K., and Australia, and 93\% were self-funded" (EFEPI, 2013, p. 12). The EFEPI report emphasizes that traveling abroad to use English in real-life situations is a key factor in the improvement of Chinese students' oral English skills: "China's English level goes up as more Chinese students and travelers head abroad" (EFEPI, 2013, p. 12). Not only Chinese students of EFL, but all EFL learners world-wide need to be prepared to manage the communication demands of a globally interconnected society (Burns, 2013; Canagarajah, 2013). However, this shift away from traditional teaching focused on grammar explanations and test scores is unavoidably associated with a series of challenges.

\section{B. What Does Research Tell Us about the Challenges of Implementing CLT?}

One of the goals of the CLT approach is to develop students' communicative competence (Canale \& Swain, 1980; Hymes, 1972) in the Target Language (TL) and the responsibility of teachers is to create the conditions in which students can develop their communicative abilities (Ballman, Liskin-Gasparro \& Mandell, 2001; Lee \& VanPatten, 2003). However, previous research on teachers' beliefs has demonstrated that beliefs and opinions about teaching are highly resistant to change, even in spite of evidence that calls those beliefs into question (Bax, 2003; Brown, 2009; Nespor, 1987; Pajares, 1992; Kumaravadivelu, 2012). This can be explained partly by the finding that there is a high likelihood that trainers' and teachers' beliefs about teaching and the methodology to be used do not match (Bax, 2003; $\mathrm{Li}, 1998$ ). This probability is even greater when trainers and teachers do not share the same cultural background. According to Li (1998), Korean teachers believe their challenges with the implementation of CLT are related to four factors: teachers, students, the educational system, and CLT itself. Related to these challenges, it is important to consider participants' learning cultures and styles, which have been discussed by Watkins and Biggs (1996), Littlewood (2000), and Reid (1995), among others, but which fall outside the scope of this paper.

Researchers have found that, even when teachers are convinced about its effectiveness and wish or try to adopt CLT, their students often prefer traditional approaches. For example, Brown (2009) found that students tend to favor a traditional language classroom, based on translation, worksheets, and grammar explanations, while many teachers claim to favor a more communicative approach. As Brown points out "what makes this finding worth mentioning is not that these teachers valued meaningful information exchange over grammar, but that their respective students did not, or at least appeared not to, value it nearly as much" (Brown, 2009, p. 53). In addition, Bateman (2008) reports that, in fact, the TBAs assigned to students in a CLT classroom demand more active involvement and more risk-taking on the part of students, which they may wish to avoid.

This reluctance on the part of students may tempt teachers to stick to the traditional ways in which they were taught (Borg, 2005; Lee \& VanPatten, 2003). Even when teachers want to try implementing better ways of teaching, they often lack the stamina, expertise, or support to follow through (Farrell, 2008). While it is not inevitable that teachers teach the way they were taught, "they must make a forcible and sustained effort to break out of the old mold. Most teachers have so much to do just to meet their daily responsibilities that they lack the energy for a break with the past" (Finkel, 2000, p. 160). As Valdés (2001) has stated, our classrooms are full of good intentions; unfortunately, however, good intentions are insufficient to respond to global communication needs.

Another factor contributing to the difficulty of implementing CLT in EFL-teaching countries is the effect of linguistic imperialism (Phillipson, 1992), which has been emphasized by several researchers (Burns, 2013; Canagarajah, 1999, 2005, 2013). Linguistic imperialism includes the export of teaching methods and materials as well as the (attempted) transfer of ideologies from English-speaking nations to EFL-teaching nations. In this regard, it is important to fully understand the power dynamics that are established between what has been described by Kachru (1986, 1992, 2006) as the Inner Circle, the Outer Circle, and the Expanding-Circle, and the teaching of EFL.

In Inner-Circle countries, English is the first dominant language; this includes the United Kingdom, the United States, Canada, Australia, and New Zealand. In Outer-Circle countries such as India, Nigeria, and Malaysia, English has a long history of presence, reputation, and institutionalized functions due to British colonialism. Finally, in Expanding-Circle countries, English is commonly studied and fulfills various and specific purposes; such is the case for example in China and Russia. As Canagarajah (2013) states "speakers in the expanding circle do not use English only for extracommunity relations. For countries such as China, Vietnam, Philippines, and Brazil, English is important for international news, popular culture, and advanced education..." (Canagarajah, 2013, p. 4). Clearly, English no longer belongs to the Inner Circle. In a wide variety of settings today, English is used more by non-native speakers than by monolingual users (British Council, 2014). Therefore, EFL teachers need to create classroom settings that engage students in real-world scenarios that foster success in international communication (Burns, 2013). This was the goal that motivated the workshops to train Chinese and Iraqi/Kurdish EFL teachers.

\section{ReSEARCh Questions AND Methodology}

The present study was motivated by two research questions: 
1. How is CLT perceived by EFL teachers who are non-native English speakers working in Expanding-Circle countries?

2. What are the main challenges preventing implementation of CLT?

\section{A. Participants}

The authors (who served as the trainers), both fluent non-native speakers of English who had trained foreignlanguage teachers in the USA for over 20 years, designed and conducted a multi-day, 25-hour training workshop on the principles and practical implementation of CLT. The workshops were conducted with university-level EFL teachers from the People's Republic of China $(n=17)$ and Iraq and Kurdistan $(n=8)$. The China group consisted of Master's program students at a university in mainland China (mostly females in their 20s) in their first or second year of EFL teaching at various levels, but most of them at the university level, whereas the Iraq/Kurdistan group consisted of midcareer EFL teachers at the university level (mostly males in their 30s and 40s; all Master's degree holders) with an average of 7 years of teaching experience in their country.

\section{B. Procedures}

Participants were asked a month before the start of the workshops to read the first three chapters of Lee and VanPatten (2003) and the first three chapters of Ballman, Liskin-Gasparro and Mandell (2001) to familiarize themselves with the fundamentals of the theory and practice of CLT. During the workshops, after the trainers modeled the main principles of CLT and provided participants with skeletal outlines of the chapters, participants engaged in coteaching by taking turns presenting their understanding of each chapter. The co-teaching was carried out in teams in front of the other workshop participants. In the case of the Iraq/Kurdistan group, the class in front of which the coteaching was carried out also included new graduate students at a university in the USA. Together with the participants, the trainers reviewed each chapter in detail, elaborating on its content, modeling the principles of CLT, and providing ample opportunities for questions and reflection. At the end of the workshops, participants submitted two lesson plans showcasing their understanding of CLT and how to apply it in their own EFL classrooms. Some participants also volunteered to be interviewed regarding their understanding of CLT and its feasibility in their teaching context.

The following data were collected in connection with the workshops:

- Written reflections submitted by all participants as part of daily class activities

- Audio-recorded interviews with 10 participants who volunteered to be interviewed. The interviews were conducted with a set of open-ended questions (see Appendix). The recordings were transcribed by a trained applied linguist.

- Lesson plans submitted by participants at the end of the workshops

- Trainers' detailed impressionistic notes on observations of participants' co-teaching practices

\section{ANALYSIS AND DISCUSSION}

The goal of the workshops was to help participants become more aware and more accepting of CLT, increase their understanding of TBAs, and develop their ability to implement CLT principles and TBA techniques in lesson plans. The workshop outcomes are reported in two parts: A) participants' perspectives and beliefs (gathered from written reflections and oral interviews); and B) characteristics of participants' lesson plans, submitted at the end of the workshops, and co-teaching practices during the workshops.

\section{A. Perspectives and Beliefs}

While demonstrating a certain level of engagement and expressing an interest in learning during the workshops, participants repeatedly voiced their opinion that CLT does not apply to the EFL teaching context of their respective countries. This is illustrated two excerpts from the oral interviews: ${ }^{1}$

Try to teach communicatively and teach communicatively in [my country] is quite difficult, it's a different setting. So what's communicative, the right communicative method in here may not be quite right, may be quite shocking in there. So the problem is with the tiny details, tiny details sometimes control the whole show. So the way I'm planning to do the communicative teaching is somehow different from you guys".

The communicative approach is still somehow, we can apply it but going a different way because, you know, the cultural settings are different.

Participants claimed that CLT does not boost test scores of grammar-focused English tests which are the main measure of student learning and teacher effectiveness in China, Iraq, and the Kurdistan region. As expressed by some of the teachers when they were asked about their experiences as English language teachers:

The focus is on grammar and drills.

Grammar has been the focus of the language teaching in [my country] but how to teach and make the boring task easier and more interesting is the one we should think more...

As some of the teachers expressed:

The only aim of learning English is for all kinds of tests.

\footnotetext{
${ }^{1}$ The written and oral comments are reproduced as they were uttered or written by participants originally; they were not edited by the authors.
} 
When we read passages, I usually ask students to read it and I explain the key points and analyze the structure of some complex sentences.

According to Anderson (1993), the greatest obstacle preventing Chinese English teachers from using CLT is the heavy responsibility placed on them to prepare their students for the English section of the national examination, as "this discrete-point, structurally-based examination does not test communicative skills" (Anderson, 1993, p. 472). The participants from Iraq and the Kurdistan region reported operating under similar constraints.

Moreover, according to the oral interviews and researcher field notes, participants from both groups stated repeatedly that if CLT were applied in their EFL teaching context, test scores would be lowered. Participants reported being under so much pressure to cover what students are expected to know for national examinations that there is "no time to do CLT", even though they might like to implement CLT.

I wish for a more open atmosphere in classroom where we can talk loud, and communicate with teachers and our partners. I wish for more opportunities to speak out my ideas though frightening at the beginning.

Thus, participants seem to prefer choosing "coverage over communication", a phenomenon reported by Ballman, Liskin-Gasparro \& Mandell (2001). As the participants frequently expressed, "there isn't enough time to do these exciting activities; we have the mandated curriculum". This also points to the participants' perception that the approach must be either traditional or CLT.

The main problem in [my country] is actually the centered teaching process. You don't have flexibility to choose the material, you don't have the flexibility to apply methods and strategies that not impose by people in charge. The first problem is that I have to be as a disciple to somebody else.

Sometimes, I speak English in class but students do not understand, then, I translate in [the native language]. I try to let students communicate each other in English... I do not know what happened to me that I can't arrange my class well.

In English class, we should speak more but not the teacher. Teachers do not encourage students to speak more and pay less attention to mistakes, make the class atmosphere more relaxing... we should make full use of the English class to practice more and communicate more.

As an EFL teacher I know grammar-teaching is not the most important thing.

Teachers cannot explain grammar clearly and we cannot not do exercises right. Practice by practice. We can't understand some grammar points. Teachers are tired and most students lose interest in English study.

[Teaching] Grammar is annoying me now but what should I do?

\section{B. Lesson Plans and Co-teaching}

At the end of the training sessions, the EFL teachers in this study perceived themselves as facilitators and users of both CLT and TBAs. They were able to summarize the theory and the tenets of the CLT and the characteristics of TBAs upon request. Nevertheless, their lesson plans included mainly traditional practices not advocated in CLT, such as lecturing and explaining. When asked to produce lesson plans featuring CLT goals and activities, most of the teachers were unable to do so, submitting lesson plans with traditional-style activities for students and teachers instead.

This approach prevailed despite the fact that several examples had been demonstrated not only during class discussions but also through short communicative sessions conducted by the trainers in other languages (unfamiliar to the participants), in which the participants acted as language students performing real-life activities using the language. Most of the objectives that teachers planned for their lessons were based on grammar goals rather than on communicative goals. In other cases, teachers had vague objectives such as "Make students have the ability to present their ideas in class", or content objectives such as "Express themselves more freely on the theme of Women". In some instances, teachers submitted lesson plans with processing objectives such as "Note-taking, the students should take some notes of important dates, names of places".

With respect to the co-teaching practices, despite having reviewed the most important principles of CLT and TBA and having observed several examples modeled by the trainers, most participants were not able to distance themselves from lecturing and providing long explanations of vocabulary and grammar concepts. Thus, although they expressed during oral interviews that the focus of their teaching practices in their English classrooms is primarily on studentcentered activities, they mostly fell short in incorporating such practices. The majority of participants continued reproducing traditional teaching strategies in which the teacher was the only one who spoke and the provider of all knowledge.

\section{IMPLICATIONS AND FUTURE RESEARCH}

According to the findings discussed above, the short answer to both research questions posed in the present study is that EFL teachers in Expanding-Circle countries approach CLT with reservations and reluctance.

It is possible that a constellation of factors contributed to these findings. However, rather than a host of interrelated factors, it appears that one fundamental fact explains most of the outcome. This fact is the clash of trainers' and participants' belief systems.

CLT is a belief system undergirded by specific perspectives on reality. Having originated in Western cultures, CLT reflects the values of freedom of expression, individual needs, and egalitarianism (McKay, 2011). Traditional teachercentered approaches to instruction, on the other hand, tend not to espouse these values (Lee \& VanPatten, 2003; McKay, 
2010). The approach commonly found in China and Iraq/Kurdistan is rooted in memorization and grammar-focused tests. As mentioned earlier, communication in CLT is understood as the use of the target language for real-world purposes. However, this emphasis on communicative competence - which includes grammatical, sociolinguistic, discourse, and strategic competence (Canale \& Swain,1980; Hymes, 1972; Savignon, 1983) - is not compatible with the belief systems held by Chinese and Iraqi/Kurdish teachers, which are rooted in their experiences of teaching and learning EFL in their respective contexts (Kumaravadivelu, 2012; Lewis \& McCook, 2002). As mentioned in the review of the literature, research on teachers has shown that beliefs about teaching are highly resistant to change, even when teachers are presented with evidence that contradicts their beliefs (Bax, 2003; Brown, 2009; Nespor, 1987; Pajares, 1992; Kumaravadivelu, 2012).

The trainers - themselves non-native speakers of English who had emigrated as adults from Expanding-Circle countries to an Inner-Circle country - were careful not to come across as trying to force teachers to adopt new ways. Attempts to impose a belief system from one culture to another constitute a form of cultural imperialism (Said, 1993; Schiller, 1973), which is closely connected with linguistic imperialism (Phillipson, 1992). Rather than imposing a belief system, the trainers attempted to introduce the tenets of CLT and demonstrate its techniques. The emphasis of the workshops was not on "this is how you should teach" but rather on "this is how EFL could be taught if the goal were English proficiency”.

While the trainers had been students in EFL classrooms until they moved to an Inner-Circle country as adults, their professional experiences were primarily with ESL contexts as opposed to EFL contexts. Ellis (1996) compares the very different realities of ESL vs. EFL contexts and illustrates the many levels of mismatch between traditional styles of teaching (commonly found in EFL contexts) and CLT. Ellis cautions against "clinging to a single concept of good teaching” (p. 218). In the same vein, Bax (2003) invites teachers and trainers to think not in terms of either/or, but in terms of both/and. Bax urges trainers and teachers to consider different ways of teaching not in absolute terms with one approach being good and all alternative ways being inferior. According to Canagarajah (2005), it is especially important to accord local, specific contexts at least as much importance as general professional mandates developed outside specific contexts.

The local shouldn't be of secondary relation or subsidiary status to the dominant discourses and institutions from powerful communities, whereby the global is simply applied, translated, or contextualized to the local. Making a space for the local doesn't mean merely "adding" another component or subfield to the paradigms that already dominate many fields. (Canagarajah, 2005, p.xiv)

The challenge then is to develop pedagogical approaches that blend local and global considerations and lead to the desired outcomes for specific local contexts at the same time that global needs are satisfied (Bax, 2003; Burns, 2013; Kumaravadivelu, 2012; McKay, 2011).

The teachers in our study declared that high English proficiency on the part of their students is the desired outcome. They measure this proficiency with test scores, using exams focused on linguistic accuracy primarily in the realm of syntax and vocabulary. While teachers and students have been focused on English test scores, the need for employees who can actually use English for employment purposes in fields such as science, banking, commerce, tourism, etc., is not being met (Crystal, 2013; Graddol, 2006; Neeley, 2012). Even in such Expanding-Circle countries as Indonesia, Brazil, and China, which were not part of the British Empire, significant percentages of public sector employers as well as private companies and NGOs report that English is used daily in their organization (British Council, 2013). Our 21 ${ }^{\text {st }}$ century, internet-connected society "places a premium on the ability to communicate in a lingua franca" (Warschauer, 2000, p. 512), namely, English - not the English of native-speaker countries (Kachru, 1992, 2006) but the English that "belongs to everyone" (Crystal, 2008), known variously as English as a global language (Crystal, 2003), English as an international language (Pennycook, 1994), English as an international lingua franca (McKay, 2011), and Globish (McCrum, 2011).

We now live in a new era, "in a society with rapid changes, one that is already substantially different from the typical manufacturing base of the past. Therefore, it's prime time to reinterpret learning" (Hongyi, 2014). In the past, passing English national exams was the main objective of English classes in EFL contexts. However, this is no longer enough. As Graddol (2013) states, "in those countries where passing English exams has been made a condition of promotion or graduation, it has often led to considerable stress and resentment by learners, rather than significantly enhanced levels of proficiency" (Graddol, 2013, p. 84). In the $21^{\text {st }}$ century, the goal should be to help students develop the kind of English proficiency that will enable them to function in the globally connected workplace, as "the ability to communicate in English is a requirement in a globalized economy" (EFEPI, 2013, p. 41). Thus, it is imperative that national exams, instruction, and assessments "be aligned with the goal of proficient English communication skills" (EFEPI, 2013, p. 41) to better respond to these needs.

As Canagarajah (2013) has stated, in this new era there is already an inevitable shift to new paradigms of teaching and assessment, in which "the changing pedagogical priorities suggest that we should focus on language awareness rather than grammatical correctness in a single variety; strategies of negotiation rather than mastery of productoriented rules; pragmatics rather than competence" (2013, p. 8, original emphasis). That is, in the new global context, proficiency is more complex and fluid and, therefore, requires a new approach (Canagarajah, 2013). While the need to 
shift to this new paradigm focused on the CLT is imperative, various and serious challenges remain for teachers and trainers.

\section{CONCLUSION}

As EFL teacher-trainers, it is our responsibility to better inform teachers of effective methodologies that will allow their students to reach the required English proficiency levels to fully function in the various communicative contexts of the $21^{\text {st }}$-century workplace. However, it is the teachers' responsibility to assess these methodologies and to make the necessary adjustments to better suit their local and national traditions while also responding to global needs.

Studies like the present one help us deepen our understanding of local, national, and global needs so that we can better prepare future EFL teachers and better equip them to develop teaching and learning materials for their classrooms (Burns, 2013; Canagarajah, 2013). Only by thoroughly analyzing all components involved in the teaching and learning of EFL will we be able to develop a more sensitive pedagogy that respects local cultures while fulfilling the requirements of the globalized economy (Kumaravadivelu, 2012; McKay, 2010). Adopting these perspectives, will enable us to create a better future in a world without communication boundaries.

\section{ACKNOWLEDGEMENT}

Research for this article was funded in part by a grant from the United States Department of State. The opinions, findings and conclusions stated herein are those of the authors and do not necessarily reflect those of the United States Department of State. The authors gratefully acknowledge the assistance of Jessica Pryor Lee and Lea Whitely Child with data collection and data transcription, respectively.

\section{APPENDIX}

Interview questions:

1. Why did you choose to be a language teacher?

2. According to your teaching philosophy,

a) What is the role of the teacher?

b) What is the role of the students?

3. As an English teacher, what are your goals for your students?

4. What strategies do you use in the classroom to achieve these goals?

5. What is the role of the textbook and other materials you use?

6 . What are the main problems or challenges that you face as a teacher?

7. What can you do to solve those problems or address those challenges?

8. How can you apply in your classroom what you have learned in this workshop?

9. What aspects of this workshop will you be able to incorporate in your teaching?

10. What are the main obstacles you may face while trying to implement in your country what you have learned in this workshop?

11. What does your ideal classroom look like?

\section{REFERENCES}

[1] Anderson, J. (1993). Is a communicative approach practical for teaching English in China? Pros and cons. System, 21(4), 471480.

[2] Ballman, T.L., Liskin-Gasparro, J.B., \& Mandell, T.B. (2001). The communicative classroom. Boston: AATSP/Heinle.

[3] Bateman, B. E. (2008). Student teachers' attitudes and beliefs about using the target language in the classroom. Foreign Language Annals, 41(1), 11-28. doi: 10.1111/j.1944-9720.2008.tb03277.x.

[4] Bax, S.J. (2003). The end of CLT: A context approach to teaching. ELT Journal, 57(3), 278-287. doi: 10.1093/elt/57.3.278.

[5] Borg, M. (2005). A case study of the development in pedagogic thinking of a pre-service teacher. TESL Electronic Journal, 9(2), 1-30.

[6] British Council (2013). Culture at work. Retrieved March 11, 2014, from http://www.britishcouncil.org/culture-at-workresearch_march_2013.pdf.

[7] British Council. (2014). Frequently Asked Questions. The English Language. Retrieved from global http://www.britishcouncil.org/learning-faq-the-english-language.htm March 11, 2014.

[8] Brown, A.V. (2009). Students' and teachers' perceptions of effective foreign language teaching: A comparison of ideals. Modern Language Journal, 93(1), 46-60. doi: 10.1111/j.1540-4781.2009.00827.x.

[9] Burns, A. (2013). English as international language: Considerations for English language teaching. In T. Nugrahenny \& C. Manara (Eds.), Contextualizing the pedagogy of English as an international language: Issues and tensions (chap. 3). New Castle UK: Cambridge Scholars Publishing.

[10] Canagarajah, A. S. (1999). Resisting linguistic imperialism in English teaching. Oxford: Oxford University Press.

[11] Canagarajah, A. S. (Ed.)(2005). Reclaiming the local in language policy and practice. Mahwah, NJ: Lawrence Erlbaum. 
[12] Canagarajah, S. (2013). Redefining proficiency in global English. In T. Nugrahenny \& C. Manara (Eds.), Contextualizing the pedagogy of English as an international language: Issues and tensions (chap. 1). New Castle UK: Cambridge Scholars Publishing.

[13] Canale, M., \& Swain, M. (1980). Theoretical bases of communicative approaches to second language teaching and testing. Applied Linguistics, 1, 1-47.

[14] Crystal, D. (2003). English as a global language. Stuttgart, Germany: Ernst Klett Sprachen.

[15] Crystal, D. (2008). Two thousand million?. English Today, 93, 3-6. doi:10.1017/S0266078408000023.

[16] Crystal, D. (2013). Foreword. In S.L. Montgomery (2013). Does science need a global language? Chicago: The University of Chicago Press.

[17] Economist, The (December 20, 2001). The triumph of English: A world empire by other means. Retrieved March 11, 2014, from http://www.economist.com/node/883997.

[18] EFEPI (2013). English First: English Proficiency Index. http://www.ef.edu/_/ /media/efcom/epi/2014/full-reports/ef-epi2013-report-master-new.pdf (retrieved March 10, 2014).

[19] Ellis, G. (1996). How culturally appropriate is the communicative approach? ELT Journal, 50(3), 213-218.

[20] Ellis, R. (2012). Language teaching research and language pedagogy. New York: John Wiley \& Sons.

[21] Farrell, T. (Ed.)(2008). Novice Language Teachers. Insights and Perspectives for the First Year. London: Equinox Publishing.

[22] Farrell, D., \& Grant, A. (2005). Addressing China's looming talent shortage. McKinsey Global Institute.

[23] Finkel, D. (2000). Teaching with your mouth shut. Portsmouth, NH: Heinemann.

[24] Graddol, D. (2006). English next: Why global English may mean the end of 'English as a Foreign Language'. British Council.

[25] Graddol, D. (2013). Profiling English in China: The Pearl River Delta. Cambridge English, UK. Retrieved March 22, 2014, from http://www.cambridgeenglish.org/images/151564-profiling-english-in-china-dg.pdf.

[26] Hongyi, W. (2014). Language is better learned in casual study, scholars say. China Daily USA, March 6, 2014.

[27] Hymes, D. H. (1972). On communicative competence. In J. B. Pride \& J. Holmes (Eds.), Sociolinguistics. Baltimore, USA: Penguin Education, Penguin Books Ltd. 269-293.

[28] Kachru, B. B. (1986). The power and politics of English. World Englishes, 5(2-3), 121-140.

[29] Kachru, B. B. (Ed.)(1992). The other tongue: English across cultures. Urbana-Champaign, IL: University of Illinois Press.

[30] Kachru, B. B. (2006). The English language in the outer circle. In World Englishes (pp. 241-255). London: Routledge.

[31] Kumaravadivelu, B. (2012). Language teacher education for a global society: A modular model for knowing, analyzing, recognizing, doing, and seeing. New York: Routledge.

[32] Lee, J., \& VanPatten, B. (2003). Making communicative language teaching happen ( $2^{\text {nd }}$ ed.). New York: McGraw-Hill.

[33] Lewis, M., \& McCook, F. (2002). Cultures of teaching: Voices from Vietnam. ELT Journal, 56(2), 146-153.

[34] Li, D. (1998). "It's always more difficult than you plan and imagine": Teacher's perceived difficulties in introducing the Communicative Approach in South Korea. TESOL Quarterly, 32(4), 677-703.

[35] Littlewood, W. (2000). Do Asian students really want to listen and obey? ELT Journal, 54(1), 31-36.

[36] McCrum, R. (2011). Globish: How the English language became the world's language. New York: Random House.

[37] McKay, S. (2010). English as an international language. N. Hornberger \& S. McKay, S. (Eds.). Sociolinguistics and language education (pp. 89-115). Ontario, Canada: Multilingual Matters.

[38] McKay, S. (2011). English as an international lingua franca pedagogy. In E. Hinkel (Ed.), Handbook of research in second language teaching and learning (chap. 8). New York: Routledge.

[39] Neeley, T. (2012). Global business speaks English. Harvard Business Review, 90(5), 116-124.

[40] Nespor, J. (1987). The role of beliefs in the practice of teaching. Journal of Curriculum Studies, 19(4), 317-328.

[41] Pajares, M.F. (1992). Teachers' beliefs and educational research: Cleaning up a messy construct. Review of Educational Research, 62, 307-332.

[42] Pennycook, A. (1994). The cultural politics of English as in international language. London: Longman.

[43] Phillipson, R.H.L. (1992). Linguistic imperialism. Oxford, UK: Oxford University Press.

[44] Reid, J. (1995). Learning styles in the EFL/ESL classroom. Heinle \& Heinle Publisher.

[45] Said, E.W. (1993). Culture and imperialism. New York: Pantheon.

[46] Savignon, S. (1983). Communicative competence: Theory and classroom practice. Addison-Wesley, Reading, Mass.

[47] Schiller, H. J. (1973). Communication and cultural domination. White Plains, NY: International Arts and Sciences Press.

[48] Valdés, G. (2001). Learning and not learning English: Latino students in American schools. New York: Teachers College Press.

[49] Warschauer, M. (2000). The changing global economy and the future of English teaching. TESOL Quarterly, 34(3), 511-535.

[50] Watkins, D.A., \& Biggs J.B. (1996)(Eds). The Chinese learner: Cultural, psychological and contextual influences. CERC and ACER, Hong Kong: The Central Printing Press. 269-285.

[51] Yang, J. (2006). Learners and users of English in China. English Today, 22(2), 3-10. DOI: 10.1017/S0266078406002021.

María Luisa Spicer-Escalante is originally from Mexico. She earned a PhD in Spanish Linguistic from the University of Illinois, Urbana-Champaign, in 2002. Serving on the linguistics faculty at Utah State University, Logan, since 2003, Dr. Spicer-Escalante has co-directed its Master of Second Language Teaching program since 2010. Her professional interests include teacher preparation, pedagogical aspects of second/dual language acquisition, bilingual writing, and sociolinguistics.

Karin deJonge-Kannan is originally from the Netherlands. She earned a $\mathrm{PhD}$ in Linguistics from Indiana University, Bloomington, in 1995. Serving on the linguistics faculty at Utah State University, Logan, since 2000, Dr. deJonge-Kannan has codirected its Master of Second Language Teaching program since 2004. Her professional interests include teacher preparation, culture learning, and pragmatics. 